\title{
The woman's international migration: Controlling rural land by women workers
}

\author{
M. Zid* \& A.R. Casmana \\ Universitas Negeri Jakarta, DKI Jakarta, Indonesia
}

\begin{abstract}
This study aims to examine the characteristics of international migration undertaken by Indonesian women. Women's international migration generally aims to meet socialeconomic needs, as well as to be able to improve the quality of one's life financially. The research method used in this study is qualitative with case studies conducted in two villages, namely Panyingkiran Village and Ciherang Village. The results of this study indicate that in general, after international migration for financial needs, the average remittance obtained from abroad is used to buy land. More specifically, the land that was bought by the women workers was rice fields with an average area of one to two hectares. It aims to develop their business and as a tool for investment in the future. In addition, the destination country which is mostly used as a place to work in the Middle East country.
\end{abstract}

Keywords: International migration, women, remittances, land tenure.

\section{INTRODUCTION}

International labor migration by women from Panyingkiran Village and Ciherang Village-West Java can be interpreted as a socio-geography as a strategy as well as a response in facing life difficulties faced by rural households. Various difficulties faced by poor households in rural communities include inequality in ownership and ownership of agricultural land between social strata, inequality of various accesses, inequitable allocation and control of economic resources (Khoo \& Yeoh 2018). Faced with various difficulties in life, each individual and household from various social strata will have different strategies. Efforts to get out of various livelihood difficulties by (Ellis 2000) is referred to as "survival strategies" and "coping strategies" which can be interpreted as a livelihood strategy undertaken a household when faced with difficulties. This economic action was intentional by households with high motivation to satisfy most basic needs, at least at a minimum level, in accordance with the social and cultural norms of the community (Ellis 2000).

Ellis (2000) explains in more detail that the strategies adopted by households to survive and improve living standards include migrating for work, both in cities and as workers abroad. For households that have limited access and agricultural land, one strategy that many family members do is to make the final choice by sending a family member. Usually, a daughter or wife - to become an international workforce overseas (Parreñas et al. 2019). Difficulties in life and the uncertainty of achieving a better life in the area of origin encourages rural women who come from disadvantaged groups, and hopes to improve their standard of living by working as a migrant in Malaysia, one of the uses of remittances used to purchase land (Butt, Ball and Beazley 2016). The rationality of an individual and family support to improve economic life and change social statuses such as getting a channel with more opportunities to become international workers in Asia Pacific countries such as Malaysia, Singapore, Hong Kong, Taiwan, South Korea, and Eastern countries Central, especially

\footnotetext{
*Corresponding author: aseprudi@unj.ac.id
} 
Saudi Arabia which still needs female workers to be employed in the domestic sector as domestic servants (PRT) which are known as jobs that are categorized as dirty, dangerous and difficult (dirty, dangerous, and difficulty) (Liao \& Gan 2020).

Migrants are interested in utilizing remittances for land because of the consideration that land as a resource, for rural residents who make a living as farmers, has economic value, and at the same time high social value (Platt et al. 2016). In other words, there is a close emotional bond between the farmer and the land he owns, as stated by Spaan and van Naerssen in 2018, that there is an emotional connection between the farmer and the land. Based on this formulation, the first question in this study is: "what is the use of remittances obtained from abroad after international migration?"

\section{METHOD}

This research is a case study by taking two villages, namely Panyingkiran Village, Rawamerta District, Karawang Regency, and Ciherang Village, Pasawahan District, Pur-wakarta Regency. Consideration of the use of case studies that the topic examined in this research is a phenomenon that is happening now in the context of real-life in the form of international migration of women, land tenure and gender equality in rural areas, especially in the two villages where the research took place. The type of data collected is primary and secondary data. Primary data obtained directly from the results of in-depth interviews (in-depth interview) with respondents and key informants. To complete the data, an FGD was conducted, which was followed by respondents, key informants. Secondary data is data obtained from the results of searches on archives, documents ranging from the level of the research village, Rawamerta and Pasawahan sub-districts, the Department of Man-power and Transmigration, BPS Karawang and Purwakarta Districts, as well as the IPB, UI, National and LIPI libraries. In this study, the data collected was analyzed using a combination of quantitative methods and qualitative methods, with more emphasis on qualitative methods.

\section{RESULTS AND DISCUSSIONS}

\subsection{Utilization of remittans and land tenure}

Land tenure by women migrants and their families is the main focus of this study. Land has an important meaning for them because most of the female migrants come from families of tunakisma farmers who make a living as farm laborers and other lower-class jobs (Listiani 2018).

The 104 female migrants from the villages of Panyingkiran and Ciherang with a working period of between four to twenty-two years are able to buy land, although in a narrow size. Most of them buy land on land, with varying sizes, the smallest land that women migrants can afford is enough to cover 60 square meters, while the largest is 800 square meters. The most extensive field of rice that can be purchased by female migrants is 1 hectare at each purchase. Findings in both villages show that a migrant, in general, can only afford to buy land after going back and forth working abroad at least three times the contract period or in the seventh and eighth years of work.

The ability of a migrant to buy land occurs after the basic needs of the family and household can be met. Thus, the use of remittances sent during the first to fourth year is generally used only to provide food and to renovate or build permanent houses (Hasanah, Mendolia and Yerokhin 2017). Only migrants who are tenacious and work several times overseas can afford to buy land. Most migrants are only able to buy land in a limited size; this is because land prices are relatively lower when compared to the price of rice fields. Only 37 times the purchase of rice fields by women migrants from Panyingkiran and Ciherang Villages. The most rational reason is that the price of rice fields continues to increase from year to year, and it is impossible to reach them with the wages they receive as domestic workers (Platt 2018). It can be seen from an example of three Indonesian women who were migrating abroad. 
There are three women migrants - one from a pioneer generation of migrants, and two from a generation of followers - who have managed to collect money from the sweat of their years of work in Saudi Arabia and accumulate wealth, including purchasing agricultural land in the form of rice fields. They are ITA (36 years), N.Yt (34 years), and Mas (65 years). ITA is a former female migrant from Panyingkiran Village who has managed to accumulate the proceeds of work for nine years into a variety of wealth such as land and paddy fields, which amounts to approximately 3.5 hectares, four-wheel open-air vehicles, and a shop for agricultural production facilities that provide various fertilizers and medicines.

N.Yt, a female migrant from Ciwelut-Panyingkiran village, was able to buy a 2-hectare rice field, and a land area of 600 square meters. Before leaving to become a domestic worker in Saudi Arabia, her parents' work was only as a "single" and a farm labourer for a wealthy family in her village. At present the economic conditions of the N.Yt family and parents can be categorized as "Jelema boga" or people who obtain provisions of daily food from the harvest of rice fields and the benefits of opening a stall in their village. Meanwhile, Mas, one of the pioneering migrants and the longest working in Saudi Arabia, who is 21 years old, was able to buy six units of paddy land which covers an area of approximately 2.5 hectares, and the entire paddy field has been distributed to five children who are married, so the economic condition of his children is even better when compared to his condition.

Regarding various slanted and unpleasant accusations from its neighbors, ITA only revealed the following:

I had heard the words of my friends and neighbours which makes me uncomfortable to hear, which is when I brought quite a lot of money from the middle east, and when I took two months off in the village, I was sent money by the employer to buy tickets back to the middle east, according to proverbs, until so the subject of village discussion, he said, I was made into a mistress's wife in a rich Arab household. But my family and I have never paid any attention to it, if it is served, it hurts, and finally the slanted talk goes away" (Interview, 3/23/2011).

Mr. ITA, namely Sup, who is a retired civil servant in class II has the consideration that his son is not likely to be strong working continuously abroad, and his son must also be married. Therefore, he feels obliged to 'nyakolakeun' or manage the money sent by his son to in the form of paddy soil and a little land. All purchases are always with the knowledge of ITA, and the purchase is in ITA's own name. According to Sup, the price of paddy land in Panyingkiran Village from year to year the price continues to rise, because it includes a first-class rice field with good irrigation, so that the yield is always profitable.

The meaning of land, in this case for migrants and their families who come from the lowest strata in the countryside or in the terminology of the local community is called the "jelema teu boga" group, very crucial; this is because it has a high social and economic function among other social functions as a backup to build a house for the family, where the house is the basic needs of every family (Liao \& Gan 2020). Economically, land functions as a savings when migrant families experience shocks due to various life difficulties such as a disaster. So land is one way out as a form of a coping strategy for every migrant family.

\subsection{Building a permanent house}

Being able to build a house, especially a permanent home, is the desire of all families because home is a basic need for everyone. In addition, the house is also often used as a measure of social status in society (Yuniarto 2016). One form of success of a migrant working abroad, among others, can be seen from the house which is generally built quite well for the size of the countryside. All women migrants claimed that the money from working abroad was used to repair or build houses, and that was the case with the second or third departure (Yuniarto 2016). Building a house in general in a gradual way was done. One of the remittance effects that women migrants send to families in the village of origin is the emergence of business opportunities in the non-agricultural sector (Butt et al. 2016). This was captured by those who previously owned land, especially those located around the village roadside. The emergence of stalls that sell daily necessities, food stalls, 
equipment kiosks and mobile phones (HP), water refill kiosks, retail gasoline kiosks are a form of business that is often chosen by migrant families. One of the migrants in Panyingkiran, who is quite successful, ITA (36 years), has a kiosk that sells a variety of agricultural production materials (saprotan) in the form of fertilizers, pesticides, spray equipment, farming equipment such as hoes, sickles and various other items needed by farmers.

The strategy of migrants is that migrants who have stalls or kiosks are building networks and emotional ties with consumers so that consumers are bound and continue to be loyal customers of their stalls or kiosks. In an interview with Cas (53 years old), a farmer in the distance of distance from Posta-Panyingkiran village, Cas claimed that for the sake of fertilizing and treating his rice fields of approximately two hectares, all were supplied by the ITA-Tas kiosk. The reason for using Cas, besides the fact that they have long known each other, ITA-Cas also allows the payment behind the alias ngebon, and pais during the harvest season, of course, with prices that have been adjusted. This condition is very helpful for Cas, because as a farmer, he has never held enough cash to capitalize his farming business. The reciprocal relationship that leads to this exchange is actually a more mutual form of protection where each party gets a balanced benefit.

\section{CONCLUSION}

This part contains the abstraction from the analysis previously presented, as well as to answer the questions and objectives of this study. Firstly, the socio-geographical setting of Panyingkiran and Ciherang Villages as agriculture-based villages places land tenure as an important element as capital to meet various needs, the land is also a measure of social strata in rural communities that are still agriculture-based. Secondly, this then became a motive for women in both regions, namely Panyingkiran Village and Ciherang Village to choose overseas migration even though they had to work in the domestic sector, namely as domestic servants as hazardous jobs and was known as dirty, dangerous and dangerous. Difficult (3 D) which has not been sought after and abandoned by local workers. Thirdly, this type of work in the domestic sphere is very vulnerable to exploitation from before departure, in the country of work, to return to the country. Fourthly, economic problems in the form of low tenure of agricultural land, lack of employment in rural areas, poverty, are the most determining factors in determining the motive for migrating rationality. In addition, a measure that still often does not receive attention is the socio-psychological aspect of the decision to migrate from rural women. At this level, education, skills, migrants possess, plus information about the language, culture of the destination country of work, working conditions are very influential in the individual's decision to migrate. Finally, international networks and the use of remittances are other important aspects of improving family welfare and severing dependence on international migration.

\section{REFERENCES}

Butt, L., Ball, J. and Beazley, H. (2016) 'False papers and family fictions: Household responses to 'gift children'born to Indonesian women during transnational migration', Citizenship Studies, 20(6-7), pp. 795-810.

Ellis, F. (2000) Rural livelihoods and diversity in developing countries. Oxford university press.

Hasanah, A., Mendolia, S. and Yerokhin, O. (2017) 'Labour migration, food expenditure, and household food security in eastern indonesia', Economic Record, 93, pp. 122-143.

Khoo, C. Y. and Yeoh, B. S. A. (2018) 'The Entanglements of Migration and Marriage: Negotiating Mobility Projects among Young Indonesian Women from Migrant-sending Villages', Journal of Intercultural Studies, 39(6), pp. 704-721.

Liao, T. F. and Gan, R. Y. (2020) 'Filipino and Indonesian migrant domestic workers in Hong Kong: their life courses in migration', American Behavioral Scientist, 64(6), pp. 740-764.

Listiani, T. (2018) 'Analysis of the Characteristics of Circular Migration: The Case of Female Domestic Workers from Rural Indonesia’, Journal of Policy Science, 26(1), pp. 149-163. 
Parreñas, R. S. et al. (2019) 'Serial labor migration: Precarity and itinerancy among Filipino and Indonesian domestic workers', International Migration Review, 53(4), pp. 1230-1258.

Platt, M. et al. (2016) 'Renegotiating migration experiences: Indonesian domestic workers in Singapore and use of information communication technologies', New Media \& Society, 18(10), pp. 2207-2223.

Platt, M. (2018) 'Migration, moralities and moratoriums: Female labour migrants and the tensions of protectionism in Indonesia', Asian Studies Review, 42(1), pp. 89-106.

Spaan, E. and van Naerssen, T. (2018) 'Migration decision-making and migration industry in the IndonesiaMalaysia corridor', Journal of Ethnic and Migration Studies, 44(4), pp. 680-695.

Yuniarto, P. R. (2016) 'Indonesian Migration Industry in Taiwan: Some socio-economic implications and improvement challenges', Jurnal Kajian Wilayah, 6(1), pp. 17-33. 